\title{
Do Institutional and Political Factors Matter for the Efficiency of Banking Sectors?
}

\author{
Małgorzata Olszak ${ }^{1}$ \\ University of Warsaw, Poland \\ Email:molszak@wz.uw.edu.pl \\ Patrycja Chodnicka \\ University of Warsaw, Poland \\ Email:pchodnicka@wz.uw.edu.pl
}

\begin{abstract}
This paper investigates the relevance of banking-sector-specific and macroeconomic determinants of profitability of 21 banking sectors over the years 1995-2009. In the analysis we apply the Arellano and Bond GMM-estimator to aggregated data collected in a harmonized way by the OECD, to find out whether banking-sector-specific and macroeconomic determinants which significantly affect the efficiency of individual banks, are also of great importance to the profitability (proxied by ROA and ROE ratios) of banking sectors. Our results suggest that banking-sector-specific determinants affect the efficiency of banks in the anticipated way. Macroeconomic variables have a statistically-significant impact on both ROA and ROE. The sensitivity of efficiency to both groups of determinants depends on institutional and political criteria.
\end{abstract}

JEL classification: C23; G21; G34

Keywords: banking sector, efficiency, business cycle, risk

\section{INTRODUCTION}

Using data from aggregated bank balance sheet and income statements from 21 countries, this paper examines internal and external determinants of profitability of banking sectors. We focus on two measures of bank efficiency, i.e. return on assets and return on equity. We investigate whether the profitability of banks operating in the OECD countries is affected by bank-specific determinants, market-structure measures and the business cycle. We also aim to find out whether diversity in sensitivity of bank efficiency to respective measures may be explained by investor protection, banking regulations and supervision as well as financial-sector structure and development.

Research on the determinants of bank profitability has usually focused on both internal factors (i.e. banks' specific characteristics) and external factors (i.e. financial market structure and

1 Corresponding author: Małgorzata Olszak, University of Warsaw, Department of Management, Szturmowa Str. 1/3, 02-678 Warsaw, Poland; email: molszak@wz.uw.edu.pl; phone:+48 (22) 5534 150, fax:+48 (22) 5534001. 
macroeconomic conditions) and has analyzed to what extent bank return on assets (ROA) and bank return of equity (ROE) is affected by those factors in a single country (Athanasoglou et al., 2008; Dietrich and Wanzenried, 2011), in country groups, e.g. the EU (Abreu and Mendez, 2001; Altunbas et al., 2001; Staikouras and Wood, 2003; Goddard et al., 2004; Pasiouras and Kosmidou, 2007), as well as studies which cross national boundaries (Mirzaei et al., 2013). Some papers focus on the influence of regulatory and institutional variables as explanatory for bank efficiency (e.g. Barth et al., 2006 and Barth et al., 2013). In previous papers authors have typically applied individual bank data (see the studies just mentioned). But some authors use also aggregated panel data (Albertazzi and Gambacorta, 2009) to study the link between different profitability measures and the business cycle. Whereas the use of individual bank information gives insight on how individual banks' profitability is affected by different determinants, the analysis of aggregated financial statement data, such as that collected in a harmonized way by OECD, allows meaningful comparisons across countries.

This paper builds on the work by Albertazzi and Gambacorta (2009) in its application of aggregated yearly dataset for OECD countries. However, unlike Albertazzi and Gambacorta, we include more countries in our sample (21 OECD countries) and use updated financial items covering the period of 1995-2009. What is more, this research studies the link between bankingsector specific, macroeconomic and matarket-structure factors in the full sample of countries as well as in sub-samples singled out with the application of institutional, regulatory, financial sector factors as well as political regional criteria. Such a research strategy allows us to look at how the profitability of banking sectors operating in comparable external environments (be it e.g. regulatory or political) respond to changes in the determinants included in our study.

Our results confirm findings from earlier studies on bank profitability. Overall, we observe some significant differences between the estimation results of the different country samples, both with respect to the significance and the size of the coefficients. The risk proxies influence both ROA and ROE, but their impact is mixed. As for our income sources and cost-efficiency factors, our findings show that banking sectors with a higher share of interest income relative to total income as well as banking sectors with higher share of non-interest income relative to total assets are significantly more profitable. The impact of indicators of macroeconomic conditions on ROA is significant in almost all sub-samples. We find that GDPG exerts positive impact on ROA. However, the results for the influence of macroeconomic conditions on ROE are mixed. The real growth of GDP has a significantly negative impact on ROE in all sub-samples except for countries with strong investor protection and with more restrictive capital regulations.

The paper is structured as follows. Section 2 surveys the relevant literature on banking efficiency. Section 3 outlines our model specification and describes dependent and independent variables used in our analyses. Section 4 presents the data sample and estimation method applied. Section 5 presents the results of our investigation. Section 6 concludes.

\section{LITERATURE REVIEW}

In the literature, bank profitability is usually expressed as a function of bank-specific (internal), macroeconomic and country-specific (external) determinants (see Dietrich and Wanzenried, 2011 as well as Athanasoglou et al., 2008 for reference). A number of recent studies have attempted to identify some of the major determinants of bank efficiency (see e.g. Dietrich and Wanzenried, 2011; Athanasoglou et al., 2008, Albertazzi and Gambacorta, 2009). The empirical results of these studies vary, since both datasets and environments differ. There exist, however, some common elements that allow a further categorization of the determinants.

Bank efficiency is measured in many different ways. Some authors consider return on average assets, whereas others focus on several dimensions of efficiency, such as net interest 
income, non-interest income, overhead costs, provisions as well as gross profit (Foos et al., 2010; Albertazzi and Gambacorta, 2009; Barth et al., 2006).

Studies dealing with internal determinants employ variables including size, capital, risk management and operational efficiency as bank-specific determinants of profitability. Size is usually introduced to account for existing economies and diseconomies of scale. Some authors find a positive and significant relationship between size and bank profitability (Pasiouras and Kosmidou, 2007). Other authors, however, provide evidence for slight impact (Berger et al., 1995) or of no impact of size on bank profitability (Micco et al., 2007).

Previous studies by Bourke (1989), Demirguc-Kunt and Huizinga (1999), Abreu and Mendes (2002), Pasioras and Kosmidou (2007) indicate that the best performing banks are those which maintain a sufficiently high level of capital relative to their assets. Such a relation may be explained by the observation that well capitalized banks tend to face lower costs of funding due to lower prospective insolvency costs (see also Athanasoglou et al., 2008).

Another determinant of bank efficiency is risk. This risk should be considered in its two basic dimensions in banking, liquidity and solvency risk. Both risk might be, but don't have to be interrelated. These two risks may also be driven by the level of credit risk resulting from bank lending activity. The research results for risk as determinant of profitability are mixed. Some papers show significantly negative relationship between the level of liquidity and profitability (Molyneux and Thornton, 1992). Abreu and Mendes (2002) who proxy risk by loan to assets ratio find positive relationship between risk and profitability. The external determinants of bank profitability are usually divided into control variables, such as interest rates and GDP growth as well as variables that represent industry specific characteristics. The latter usually refer to market concentration, industry size and ownership structure (see e.g. Dietrich and Wanzenried, 2011). Some authors examine the connections between the efficiency of individual banks and national regulatory strategies (see Barth et al., 2006: 224-235).

To the best of our knowledge, no previous study has investigated the determinants of diversity in relationship between banking sector efficiency and business cycle in a cross country study. A recent paper by Albertazzi and Gambacorta (2009) analyzing the role of macroeconomic variables for aggregated profitability of 10 industrialized countries is only very loosely related to our study. First, it does not analyze the relationship between bank profitability and business cycle together with balance sheet items. Second, it does not address the problem of factors which are behind the phenomenon of diversified cyclicality of efficiency of European banks.

\section{DETERMINANTS OF BANK PROFITABILITY}

This section describes the explanatory variables which we use to analyze banking sectors efficiency in its two dimensions, i.e. net interest income and net provisions for loan losses. They include banking-sector-specific, macroeconomic and country-specific institutional variables.

Table 1 lists the variables used in this study. Following on from the literature on banking, the profitability measures are net returns on average assets (ROA) and net returns on average bank equity (ROE) $)^{2}$, which indicate how effectively banks' assets and equity are being managed to generate revenues. ROA is a key measure of assessment of bank profitability (Golin, 2001) and therefore it has been widely applied in earlier research into factors influencing bank profitability (Athanasoglou et al., 2008; Pasiouras and Kosmidou, 2007; Dietrich and Wanzenried, 2011; Micco et al., 2007). Its drawback is the fact that it does not take into account the impact of off-balance sheet activities (i.e. the denominator of the ROA includes only on-balance-sheet assets).

We employ averages in order to capture any differences that appear in assets and equity during the fiscal year. 
Table 1

Definitions, notation and the expected effect of the explanatory variables on bank profitability

\begin{tabular}{|c|c|c|c|c|}
\hline Variable & Measure & Notation & \multicolumn{2}{|c|}{ Expected impact on: } \\
\hline Dependent: & Return on Assets, & ROA, & ROA & ROE \\
\hline Efficiency & Return on Equity & ROE & & \\
\hline \multicolumn{5}{|l|}{ Determinants: } \\
\hline \multicolumn{5}{|l|}{ Banking sector specific: } \\
\hline - Solvency risk & - Bank capital/total assets & CAP & + & + \\
\hline - Liquidity risk & - (Loans - deposits)/loans & LIQGAP & + & + \\
\hline - Credit risk & - Net loan loss provisions/average loans & LLP/Loans & - & - \\
\hline - Interest income ratio & $\begin{array}{l}\text { - Net interest income/total generated } \\
\text { revenues }\end{array}$ & IINC/TINC & $+/-$ & $+1-$ \\
\hline - Non-interest income ratio & - Non-interest income/ total average assets & NON/A & $+/-$ & $+/-$ \\
\hline - Cost-income ratio & - Total expenses/total generated revenues & $\mathrm{C} / \mathrm{I}$ & - & - \\
\hline - Funding costs ratio & $\begin{array}{l}\text { - Deposit related interest costs/ total average } \\
\text { deposits }\end{array}$ & FUNCOST & - & - \\
\hline - Bank size & - Natural logarithm of assets & SIZE & $?$ & $?$ \\
\hline \multicolumn{5}{|l|}{$\begin{array}{l}\text { Market structure } \\
\text { and macroeconomic: }\end{array}$} \\
\hline - 3-firm concentration ratio & - Three biggest banks market share & $3 \mathrm{~B}$ & + & + \\
\hline - Business cycle & - Real GDP growth rate & GDPG & + & + \\
\hline - Short term interest rate & - Money market rate & MMIR & - & - \\
\hline - Long term interest rate & - 10-year government bonds yield & LTIR & $?$ & $?$ \\
\hline
\end{tabular}

ROE is related to ROA through bank financial leverage, which is often referred to as the equity multiplier. These ratios usually increase with increases of bank leverage. The use of ROE as a measure of profitability may be troublesome, because on the one hand it disregards the risks associated with high leverage and on the other hand its levels are strongly affected by capital standards (i.e. Basel Committee capital accord). Therefore ROA emerges as a key measure for the evaluation of bank profitability (Athanasoglou et al., 2008).

\subsection{Banking sector specific variables}

As banking-sector-specific determinants of bank efficiency we use risk measures (i.e. solvency, liquidity and credit risk), operating efficiency measures (net interest income, non-interest income, cost-to-income ratio, funding-costs ratio) and a bank-size measure.

We use capital-to-assets ratio as a measure of solvency risk. Anticipating the effect of changes in this variable is complex. Extreme values of capital ratio (both too high as well as too low) are not desirable in terms of bank operating efficiency. Banks which are sufficiently capitalized are safer and remain profitable even in times of economic difficulties. Such banks benefit from both reduced funding costs and reduced need for external financing, which may have a positive effect on their profitability. From this point of view, the capital ratio should positively affect bank efficiency.

Liquidity gap is our measure of liquidity risk. We measure this risk as customer lending less customer borrowing, normalized by customer lending. Negative values for this ratio suggest low 
liquidity risk. The higher the positive value of liquidity gap the higher is the liquidity risk. It is, however, expected that, on the one hand, an excessively negative value of liquidity gap may be a proof of bank's inability to convert deposits into income-earning assets, and reflect a bank's operating inefficiency. On the other hand, extremely large positive values of this measure indicate excessive dependence of banks on retail money markets, which may bring about a vulnerability of banks to financial crises (as was observed during the recent crisis). Under the assumption that values of liquidity gap are not extreme, we expect that bank profitability will be positively related to this measure.

Credit risk is proxied by loan-loss provision to loans ratio (LLP/LOANS). Theory and empirical evidence suggest that increased exposure to credit risk is normally associated with decreased firm efficiency, and therefore, we expect a negative relationship between ROA (ROE) and LLP/LOANS (Athanasoglou et al., 2008; Dietrich and Wanzenried, 2011).

Net interest income to total interest income (IINC/TINC) related to profitability shows to what extent banking sectors' profitability is affected by traditional banking activities (i.e. interest operations). Generally this ratio should exert positive influence on bank profitability.

Non-interest income (NON/A) divided by average assets measures the relative importance of fee and commission income as well as trading operations' income. Because margins in fee and commission income and trading operations are usually higher than margins in interest operations as well as (due to banking sector liberalization and deregulation) becoming a more and more significant part of bank operating income, we expect a positive relationship between bank profitability and NON/A.

The cost to income ratio $(\mathrm{C} / \mathrm{I})$ is used to measure the impact of efficiency in expenses management on banks performance. This ratio shows the costs of running the bank, the major part of which is staff salaries and benefits, excluding losses due to bad and non-performing loans. This measure is expected to have a negative impact on a bank's profitability (Pasiouras and Kosmidou, 2007).

Funding costs are defined as interest expenses over average total deposits. They may be affected by a bank's external credit rating, competition on the funding market, market interest rates, and by the composition of the sources of funds as well as the relative importance of those sources (Dietrich and Wanzenried, 2011). Overall, we expect better profitability ratios from banking sectors that are able to raise funds more cost effectively.

Banking sector assets are our measure of banking sector size. We expect that this variable will be positively related to bank profitability (see Dietrich and Wanzenried, 2011:312; Mirzaei et al., 2013). This is because larger banking sectors with larger banks are likely to have a higher degree of product- (e.g. loans or assets) and, therefore, risk-diversification than smaller banking sectors (Smirlock, 1985). They should also benefit from economies of scale. However, banks that have become extremely large might show a negative relationship between size and profitability. This is due to agency costs, the overheads of bureaucratic processes, and the other costs related to managing extremely large banks (Pasiouras and Kosmidou, 2007; Athanasoglou et al., 2008; Dietrich and Wanzenried, 2011; Mirzaei et al., 2013). Hence, the size-profitability relationship may be expected to be non-linear.

\subsection{Market structure and macroeconomic variables}

In addition to the banking-sector-specific variables described above, in our analysis we include one market structure determinant and a set of macroeconomic variables, which we expect to have an effect on profitability. Our market structure measure is the largest-banks- concentration ratio, which is an estimate of the extent to which the largest banks contribute to activity in the banking industry. Following Beck et al. (2009) we measure bank market-concentration as the fraction of 
bank assets held by the three largest banks in a country ${ }^{3}$. The degree of concentration of a market is expected to have a negative influence on competition in the market, hence it is likely to raise banks' profits.

We focus on three macroeconomic determinants: real GDP growth, money-market and longterm interest rates, which have also been included in previous studies mentioned above. GDP growth may impact on net interest income (by lending activity) and loan-loss provisions (by credit quality). The improvement in macroeconomic conditions increases demand for credit by enterprises and households, and therefore has a positive effect on banks' profitability (Albertazzi and Gambacorta, 2009). In contrast, poor macroeconomic conditions can worsen the quality of the bank's loan portfolio and consequently generate credit losses and increase loan-loss provisions charged to the income statement of banks. These losses will result in decreasing efficiency of the banking sector. According to Athanasoglou et al. (2008), GDP growth has a positive effect on banks' profitability, possibly due to an increase in lending rates with declining probability of default. However, the level of economic activity also affects the supply of funds such as deposits, and if supply of this funds decreases due to a rise in consumption in line with GDP growth, the sign of the sensitivity parameter may become negative (Mirzaei et al., 2013).

Low interest rates in an economy prevailing in economic booms usually result in higher degree of competition among banks. This may possibly cut the opportunity for banks to get appropriate prices for lending and deposits activity. It puts downward pressure on banks' interest margin and consequently negatively influences profitability of banks'. On the other hand, high interest rates could result in debt-repayment difficulty among borrowers. Consequently, increasing interest-rate payments may lead to a higher number and volume of non-performing loans. Among the studies which focus on the relationship between interest rates and bank efficiency are Demirguç-Kunt and Huizinga (1999), García-Herrero et al. (2009) and Staikouras and Wood (2003). As those studies show, the direction of relationship between bank profitability and interest rates may be non-linear (i.e. both, positive and negative).

\subsection{Country variables}

Relative differences between institutional conditions prevailing in European countries will be captured by three determinants: investor protection, bank regulation and supervision as well as structure and development of financial sector. Strong institutional environments would result in more stable bank income (Fonseca and Gonzalez, 2008) and may be exhibited by higher profitability. Fonseca and Gonzalez (2008) found that income-smoothing (and earnings management) is weaker in countries with stronger institutions. As some authors argue (Albertazzi and Gambacorta, 2009:407), earnings management by provisions reduces pro-cyclicality of provisions. We therefore expect that the sensitivity of profitability measures to the business cycle is reduced in countries whose institutional conditions are better.

To measure investor protection we use two variables, the first self-dealing index (ANTI), drawn from Djankov et al. (2008)) and the other - creditor rights protection index (CREDITOR), taken from Djankov et al. (2007)). Higher values of both indices suggest better investor protection.

The characteristics of bank regulation in each country are incorporated through a measure of the scope of activities permitted to banks (REGRESTR) and the capital-regulatory (CR) index constructed by Barth et al. (2006). Higher values of both indices indicate higher restrictiveness.

As the supervisory effectiveness variable we incorporate official supervisory power (OFFSUP) and private-sector monitoring (PRIVMON) developed by Barth et al. (2006 and 2013). Higher values for both indices suggest greater supervisory powers.

In many previous studies, the researchers used the fraction of assets held by four or five largest banks in a country. Since in our sample, several countries (e.g. Estonia, the Czech Republic and Slovakia) have a relatively small number of banks, we employ a three-firm concentration ratio. 
As a measure of financial-sector development (FINDEV) and of financial-sector structure (FINSTR) we apply the aggregated variable constructed by Beck and Levine (2002), for the comparative activity and size of securities markets and banks, with higher values of these two variables indicating a more market-oriented financial system. The variables necessary to calculate this index will be taken from the Beck et al. (2009) database, updated for current data. Following the Beck and Levine (2002) technique, we calculate the first principal component of the variables constituting both FINDEV and FINSTR.

\section{DATA SOURCES, DESCRIPTIVE STATISTICS AND ESTIMATION TECHNIQUE}

Although the data available in the OECD database cover the period of 1979-2009, in our study we apply data spanning the period of 1995-2009. Our decision is motivated by the limited availability of institutional variables. This lack of country-specific variables arises from the fact that the indices which are of interest to our study were constructed in the late 1990s

As banking sector specific determinants of bank efficiency we employ ratios calculated from income statement and balance sheet items collected by the OECD in a standardized way which minimizes the effects of differences in accounting and statistical definitions and, therefore, allows us to carry out an in-depth analysis of differences across countries.

Macroeconomic variables, comprising real growth in GDP and inflation rate, are taken from the IMF. Data on money market rate and long term government interest rate is collected Thomson Reuters database.

Country-specific variables are taken from Djankov et al (2007, 2008), Barth et al. (2006, 2013) and Beck et al. (2009).

The concentration sector variable, i.e. the three largest banks share in the banking market, is taken from the Beck et al. (2009) database.

Table 2 reports descriptive statistics for the variables used in our analyses and Table 3 demonstrates the degree of correlation amongst dependent and independent variables.

Table 2

Descriptive statistics

\begin{tabular}{llcccc}
\hline \hline Variable & Obs & Mean & Std. Dev. & Min & Max \\
\hline ROA & 361 & 0.007 & 0.007 & -0.040 & 0.032 \\
ROE & 365 & 0.096 & 0.097 & -0.790 & 0.313 \\
NON/A & 361 & 0.014 & 0.018 & -0.021 & 0.231 \\
CAP & 365 & 0.064 & 0.022 & 0.023 & 0.162 \\
LIQGAP & 365 & 0.006 & 0.318 & -1.397 & 0.620 \\
LLP/LOANS & 365 & 0.007 & 0.010 & -0.040 & 0.073 \\
C/I & 316 & 0.827 & 0.083 & 0.586 & 1.226 \\
IINC/TINC & 341 & 0.792 & 0.104 & 0.205 & 1.257 \\
FUNCOST & 354 & 0.057 & 0.029 & 0.013 & 0.203 \\
SIZE & 370 & 14.112 & 2.280 & 6.900 & 21.209 \\
3B & 314 & 70.659 & 19.181 & 19.578 & 99.973 \\
GDPG & 389 & 2.943 & 3.154 & -14.072 & 11.736 \\
MMIR & 370 & 5.125 & 4.058 & 0.329 & 27.690 \\
LTIR & 319 & 5.172 & 1.546 & 2.096 & 12.206 \\
\hline \hline
\end{tabular}


Table 3

Correlation matrix

\begin{tabular}{|c|c|c|c|c|c|c|c|c|c|c|c|c|c|c|}
\hline & ROA & ROE & NON/A & CAP & LIQGAP & $\begin{array}{c}\text { LLP/ } \\
\text { LOANS }\end{array}$ & $\mathrm{C} / \mathrm{I}$ & $\begin{array}{l}\text { IINC/ } \\
\text { TINC }\end{array}$ & $\begin{array}{c}\text { FUN } \\
\text { COST }\end{array}$ & SIZE & $3 \mathrm{~B}$ & GDPG & MMIR & LTIR \\
\hline ROA & 1.000 & & & & & & & & & & & & & \\
\hline ROE & 0.869 & 1.000 & & & & & & & & & & & & \\
\hline NON/A & 0.649 & 0.496 & 1.000 & & & & & & & & & & & \\
\hline CAP & 0.500 & 0.112 & 0.493 & 1.000 & & & & & & & & & & \\
\hline LIQGAP & -0.280 & -0.227 & -0.342 & -0.128 & 1.000 & & & & & & & & & \\
\hline LLP/LOANS & -0.539 & -0.607 & -0.097 & 0.099 & 0.320 & 1.000 & & & & & & & & \\
\hline $\mathrm{C} / \mathrm{I}$ & -0.509 & -0.319 & -0.348 & -0.657 & -0.233 & -0.217 & 1.000 & & & & & & & \\
\hline IINC/TINC & -0.609 & -0.498 & -0.803 & -0.466 & 0.120 & 0.188 & 0.556 & 1.000 & & & & & & \\
\hline FUNCOST & -0.307 & -0.175 & -0.170 & -0.393 & 0.156 & 0.140 & 0.539 & 0.499 & 1.000 & & & & & \\
\hline SIZE & -0.350 & -0.228 & -0.274 & -0.359 & 0.338 & 0.110 & 0.191 & 0.142 & 0.268 & 1.000 & & & & \\
\hline $3 \mathrm{~B}$ & 0.043 & 0.031 & -0.047 & -0.018 & 0.070 & -0.217 & 0.014 & -0.027 & -0.163 & -0.032 & 1.000 & & & \\
\hline GDPG & 0.611 & 0.554 & 0.340 & 0.099 & -0.229 & -0.418 & -0.042 & -0.152 & 0.038 & -0.369 & 0.018 & 1.000 & & \\
\hline MMIR & 0.232 & 0.082 & 0.478 & 0.287 & -0.283 & 0.083 & 0.112 & 0.006 & 0.407 & -0.264 & 0.009 & 0.318 & 1.000 & \\
\hline LTIR & 0.205 & 0.026 & 0.521 & 0.376 & -0.251 & 0.090 & 0.024 & -0.106 & 0.228 & -0.255 & 0.074 & 0.180 & 0.792 & 1.000 \\
\hline
\end{tabular}

\subsection{Institutional indices sub-sample}

As has been stated in previous section we take into account eight determinants as institutional variables. We consider indices measuring the quality of investor protection, restrictiveness of bank regulation and supervision as well as the structure and development of the financial sector. We divide our full sample of countries into sub-samples, with the median values of those indices employed as cut-off points. Countries whose values in the indices are higher than the median value constitute our sub-samples for which separate regressions are run. The basic model we estimate in the full sample of countries is given by Equation (1) below:

$$
y_{i, t}=\sum_{k=1}^{2} \alpha_{k} y_{j, t-k}+\sum_{k=0}^{2} \beta_{k} x_{j, t-k}+\sum_{k=0}^{2} \gamma_{k} z_{j, t-k}+\theta_{t} T_{t}+\mu_{j}+\varepsilon_{j, t,} \quad \text { Eq. (1) }
$$

where:

$y_{i, t}$ is the income statement component examined (return on assets ( $\left.\mathrm{ROA} j, t\right)$, return on equity (ROEj,t));

$x_{j, t}$ is a vector of explanatory variables, i.e.:

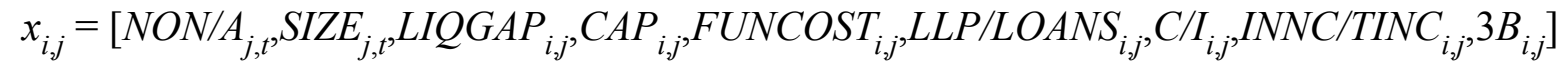

where: $N O N / A_{j, t}$ is the value of non-interest income to the total assets; $S I Z E_{j, t}$ is the logarithm of the value of the banking sector assets, $L I Q G A P_{i, j}$ is the liquidity gap, $C A P_{i, j}$ is the capital to assets ratio, $F U N C O S T_{i, j}$ is the total amount of interest expenses divided by total deposits, $L L P / L O A N S_{i, j}$ is the total value of net provisions divided by the average loans, $C / I_{i, j}$ is the total cost without net provisions to the total income; INNC/TINC ${ }_{i, j}$ is the value of the total interest income to the interest income, $3 B_{i, j}$ is the value of assets of the third biggest banks to the total assets; $z_{j, t}$ is a vector of explanatory variables, i.e.: 


$$
z_{j, t}=\left[G D P G_{i, j}, M M I R_{i, j}, L T I R_{i, j}\right]
$$

where:

$G D P G_{i, j}$ is the GDP growth, $M M I R_{i, j}$ is the money market rate, $L T I R_{i, j}$ is the long-term government bond interest rate.

We rerun this model in sub-samples singled out with the median cut off point technique. We have distinguished eight such sub-samples: ANTI, CREDITOR, REGRESTR, OFFSUP, PRIVMON, CR, FINSTR, FINDEV. ANTI is the dummy variable that takes a value of " 1 " for the anti-self-dealing index value greater than the median. CREDITOR is the dummy variable that takes a value of " 1 " for the creditor-rights-protection index value greater than the median. REGRESTR is the dummy variable that takes a value of "1" for the value of the index of the scope of activities permitted to banks greater than the median. OFFSUP is the dummy variable that takes a value of " 1 " for an official-supervisory-power index value greater than the median. PRIVMON is the dummy variable that takes a value of " 1 " for the private-sector-monitoring index value greater than the median. $C R$ is the dummy variable that takes a value of " 1 " for countries in which the capital regulations are more restrictive, i.e. take a value higher than the median. FINSTR is the dummy variable that takes a value of " 1 " for is measure of financial-sector-structure higher than the median. FINDEV is the dummy variable that takes a value of " 1 " for the financial-sectordevelopment index value greater than the median.

$T_{t}$ is a vector of year-dummies;

$\mu_{j}$ is an unobservable time-invariant country effect.

\subsection{Political criterion sub-samples}

In this step we conduct our analysis in six sub-samples. In the first we consider the full sample of countries. In the second we examine all European countries. Next are included countries which belong to the European Union. The fourth sub-sample was made up of the Eurozone countries. The two last sub-samples contain particulars on Central and Eastern Europe and the countries that are outside Europe. The final version of the model is given by Equation (2) below:

$$
y_{i, t}=\sum_{k=1}^{2} \alpha_{k} y_{j, t-k}+\sum_{k=0}^{2} \beta_{k} x_{j, t-k}+\sum_{k=0}^{2} \gamma_{k} z_{j, t-k}+\theta_{t} T_{t}+\mu_{j}+\varepsilon_{j, t},
$$

where:

$y_{i, t}$ is the income statement component examined (return on assets (ROAj,t), return on equity $(\mathrm{ROEj}, \mathrm{t})$ ) for: all countries, European countries, countries belong to the European Union, Eurozone countries, countries classified as belonging to Central and Eastern Europe and countries that are not part of Europe;

$x_{j, t}$ is a vector of explanatory variables, i.e.:

$$
x_{i, j}=\left[N O N / A_{j, t}, S I Z E_{j, t}, L I Q G A P_{i, j}, C A P_{i, j}, F U N C O S T_{i, j}, L L P / L O A N S_{i, j}, C / I_{i, j}, I N N C / T I N C_{i, j}, 3 B_{i, j}\right] \text {, }
$$

$z_{j, t}$ is a vector of explanatory variables, i.e. :

$$
z_{j, t}=\left[G D P G_{i, j}, M M I R_{i, j}, L T I R_{i, j}\right]
$$

where:

$G D P G_{i, j}$ is the GDP growth, $M M I R_{i, j}$ is the money market rate, $L T I R_{i, j}$ is the long-term government bond interest rate. 


\section{Table 4}

Country groups singled out according to median values of institutional, regulatory, financial development and financial structure determinants as well as following political division criterion

\begin{tabular}{|c|c|c|c|c|c|c|c|c|c|c|c|c|c|c|c|}
\hline & Country &  & 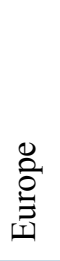 & p & 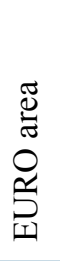 & 崩 & 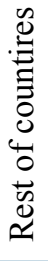 & 它 & 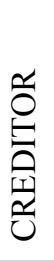 &  & 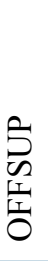 & 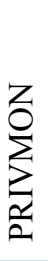 & 艺 & $\begin{array}{l}\underline{\underline{G}} \\
\text { 兄 } \\
\underline{Z} \\
\underline{I}\end{array}$ & 至 \\
\hline 1 & Austria & $\mathrm{X}$ & $\mathrm{X}$ & $\mathrm{X}$ & $\mathrm{X}$ & & & & $\mathrm{X}$ & & $\mathrm{X}$ & & $\mathrm{X}$ & $\mathrm{X}$ & \\
\hline 2 & Belgium & $\mathrm{X}$ & $\mathrm{X}$ & $\mathrm{X}$ & $\mathrm{X}$ & & & $\mathrm{X}$ & $\mathrm{X}$ & $\mathrm{X}$ & $X$ & & $\mathrm{X}$ & $\mathrm{X}$ & \\
\hline 3 & Canada & $\mathrm{X}$ & & & & & $\mathrm{X}$ & $\mathrm{X}$ & & & & $\mathrm{X}$ & & & $\mathrm{X}$ \\
\hline 4 & Chile & $\mathrm{X}$ & & & & & $\mathrm{X}$ & & & $\mathrm{X}$ & & & & & \\
\hline 5 & $\begin{array}{l}\text { Czech } \\
\text { Republic }\end{array}$ & $\mathrm{X}$ & $\mathrm{X}$ & $\mathrm{X}$ & & $\mathrm{X}$ & & & $\mathrm{X}$ & $\mathrm{X}$ & $\mathrm{X}$ & & & $\mathrm{X}$ & \\
\hline 6 & Denmark & $\mathrm{X}$ & $\mathrm{X}$ & $\mathrm{X}$ & & & & $X$ & $\mathrm{X}$ & $\mathrm{X}$ & & $\mathrm{X}$ & & $\mathrm{X}$ & \\
\hline 7 & Estonia & & & & & $\mathrm{X}$ & & & & & $\mathrm{X}$ & & & & \\
\hline 8 & Finland & $\mathrm{X}$ & $\mathrm{X}$ & $\mathrm{X}$ & $\mathrm{X}$ & & & $\mathrm{X}$ & & & & $\mathrm{X}$ & & & $\mathrm{X}$ \\
\hline 9 & France & $\mathrm{X}$ & $\mathrm{X}$ & $\mathrm{X}$ & $\mathrm{X}$ & & & & & & & & $\mathrm{X}$ & & $\mathrm{X}$ \\
\hline 10 & Germany & $\mathrm{X}$ & $\mathrm{X}$ & $\mathrm{X}$ & $\mathrm{X}$ & & & & $\mathrm{X}$ & & & & $\mathrm{X}$ & $\mathrm{X}$ & $\mathrm{X}$ \\
\hline 11 & Ireland & $\mathrm{X}$ & $X$ & $X$ & $\mathrm{X}$ & & & $\mathrm{X}$ & & & & $X$ & & $\mathrm{X}$ & \\
\hline 12 & Israel & & & & & & & & & & & & & & \\
\hline 13 & Italy & $\mathrm{X}$ & $\mathrm{X}$ & $\mathrm{X}$ & $\mathrm{X}$ & & & $\mathrm{X}$ & $\mathrm{X}$ & $\mathrm{X}$ & & & & & $\mathrm{X}$ \\
\hline 14 & Korea & $\mathrm{X}$ & & & & & $\mathrm{X}$ & $\mathrm{X}$ & $\mathrm{X}$ & $\mathrm{X}$ & & $\mathrm{X}$ & & & $\mathrm{X}$ \\
\hline 15 & Luxembourg & $\mathrm{X}$ & $\mathrm{X}$ & $\mathrm{X}$ & $\mathrm{X}$ & & & & & & $\mathrm{X}$ & & $\mathrm{X}$ & & \\
\hline 16 & Mexico & & & & & & & & & $\mathrm{X}$ & $\mathrm{X}$ & & $\mathrm{X}$ & & \\
\hline 17 & Netherlands & $\mathrm{X}$ & $\mathrm{X}$ & $\mathrm{X}$ & $\mathrm{X}$ & & & & $\mathrm{X}$ & & & $\mathrm{X}$ & $\mathrm{X}$ & & $\mathrm{X}$ \\
\hline 18 & New Zealand & & & & & & & & & & & & & & \\
\hline 19 & Norway & $\mathrm{X}$ & $\mathrm{X}$ & & & & & $\mathrm{X}$ & $\mathrm{X}$ & $\mathrm{X}$ & & & $\mathrm{X}$ & $\mathrm{X}$ & $\mathrm{X}$ \\
\hline 20 & Poland & $\mathrm{X}$ & $\mathrm{X}$ & $\mathrm{X}$ & & $\mathrm{X}$ & & & & $\mathrm{X}$ & $\mathrm{X}$ & $\mathrm{X}$ & & $\mathrm{X}$ & \\
\hline 21 & Slovakia & $\mathrm{X}$ & $\mathrm{X}$ & $\mathrm{X}$ & $\mathrm{X}$ & $\mathrm{X}$ & & & $\mathrm{X}$ & $\mathrm{X}$ & $\mathrm{X}$ & & & $\mathrm{X}$ & \\
\hline 22 & Slovenia & $\mathrm{X}$ & $\mathrm{X}$ & $\mathrm{X}$ & $\mathrm{X}$ & $\mathrm{X}$ & & & $\mathrm{X}$ & $\mathrm{X}$ & $\mathrm{X}$ & & $\mathrm{X}$ & $\mathrm{X}$ & \\
\hline 23 & Spain & $\mathrm{X}$ & $\mathrm{X}$ & $\mathrm{X}$ & $\mathrm{X}$ & & & & $\mathrm{X}$ & & $\mathrm{X}$ & $\mathrm{X}$ & $\mathrm{X}$ & & $\mathrm{X}$ \\
\hline 24 & Sweden & $\mathrm{X}$ & $\mathrm{X}$ & $\mathrm{X}$ & & & & & & $\mathrm{X}$ & & & & & $\mathrm{X}$ \\
\hline 25 & Switzerland & $\mathrm{X}$ & $\mathrm{X}$ & & & & & & & & $\mathrm{X}$ & & $\mathrm{X}$ & & $\mathrm{X}$ \\
\hline 26 & United States & & & & & & & & & & & & & & \\
\hline
\end{tabular}

\subsection{Estimation technique}

To examine the link between banking profitability change in European countries as well as the direction of the relationship we employ panel data models. We use the one-step Arella-Bond (1991) GMM-difference estimator for panel data with a lagged dependent variable, and if the specification tests render it necessary, we apply the two-step estimation technique based on the Windmeijer test. 
Due to the fact that the consistency of GMM estimator depends on the validity of instruments applied in the model (1), we consider two specification tests suggested by Arellano and Bond (1991). Only for homoscedastic error term does the Sargan test have an asymptotic chi-squared distribution. In fact, Arellano and Bond (1991) show that the one-step Sargan test over-rejects in the presence of heteroscedasticity. Rejection of the null hypothesis suggests that the overidentifying restrictions are valid and implies that we need to reconsider our model or our instruments, unless we attribute the rejection to heteroscedasticicty in the data-generating process. The alternative is the two-step estimator. ${ }^{4}$

The Arellano-Bond test measures first and second-order autocorrelation in the first-differenced errors. When the idiosyncratic errors are independently and identically distributed, the firstdifferenced errors are first-order serially correlated.

Arellano and Bond recommend against using the two-step non-robust results for inference on the coefficients because the standard errors tend to be biased downward. To overcome this problem we also apply the Windmeijer test.

\section{ESTIMATION RESULTS}

Tables 5 and 6 report the empirical estimation of Eq. (1) for banking sectors' ROA and ROE, respectively. In both tables, the first column presents the results when all countries are simultaneously considered. Columns 2 to 9 present the results when we split the banks according to the institutional, regulatory and financial factors.

Our estimation results point out to stable coefficients. The equations indicate that a negative first-order autocorrelation is present. However, this does not imply that our estimates are inconsistent. Inconsistency would be implied if second-order autocorrelation was present (Arellano and Bond, 1991). But we reject this case, because second-order autocorrelation is not present, as is implied by MA test values.

Our lagged dependent variable measures the degree of persistence of our profitability measures. In our study coefficients on this variable are not that high and not in all cases statistically significant, suggesting that the profit persistence of OECD banking sectors is weak. Our results are therefore comparable to those obtained by Goddard et al. (2004) for European banks.

Overall, we observe some significant differences between the estimation results of the different country samples, both with respect to the significance and the size of the coefficients. The solvency risk proxied by CAP, does not have a significant impact on bank ROA in the full sample of countries. However, it has a positive and significant impact on bank profitability in countries with strong investor protection (ANTI and CREDITOR), with better private monitoring of banks (PRIVMON), with more restrictive capital regulations (CR) as well as in countries whose financial sector is better developed (FINDEV). These results imply that bank profitability, proxied by ROA, declines with rising solvency risk. As for the ROE, the influence of CAP is significantly negative in the full sample, and in almost all sub-samples except for countries with more stringent capital regulations (CR), with better private monitoring (PRIVMON) and with stronger investor protection proxied by anti-self-dealing index (ANTI). Such findings imply that the higher the solvency risk the higher the profitability (the ROE).

The Sargan statistic cannot be calculated after requesting a robust VCE, but robust test for serial correlation are available. 


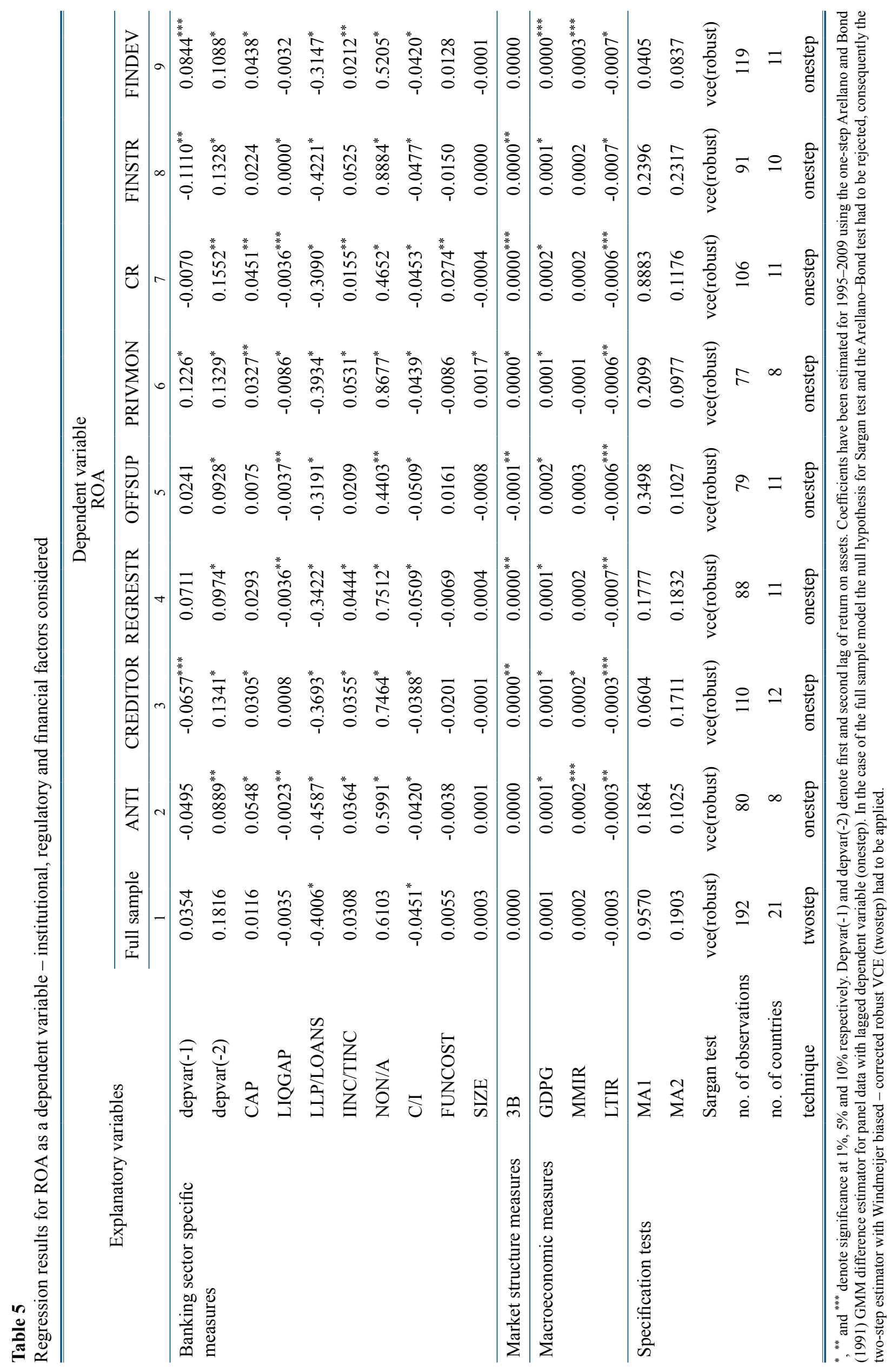







Referring to liquidity, the results are mixed. The liquidity gap (LIQGAP) in the full sample is statistically insignificant and negative for both ROA and ROE. When we analyze the sub-samples of countries, the coefficient on LIQGAP is statistically significant and LIQGAP exerts negative influence on ROA in countries with strong investor protection (ANTI), with more restrictive bank regulations (REGRESTR), with more restrictive official supervisory powers (OFFSUP), with better private monitoring of banks (PRIVMON), with more restrictive capital regulations (CR). Only in those countries whose structure of financial sector is more sophisticated (FINSTR) is the relationship between ROA and LIQGAP positive. Overall, the negative impact of LIQGAP (which has been found in our study) on ROA and ROE implies that in countries which we examine, traditional sources of bank income are not that important as a determinant of bank profitability.

The loan-loss provisions to loans ratio (LLP/LOANS) exerts negative and statistically significant influence on banking sectors profitability (ROA and ROE). Its impact on ROA is stronger in countries with better investor protection (ANTI) and with more elaborated structure of financial sector (FINSTR). In the rest of the sub-samples LLP/LOANS influence on ROA is weaker. As for the ROE, the influence of LLP/LOANS is stronger (i.e. more negative) than in the full sample, for countries with better investor protection (ANTI and CREDITOR), with stronger private monitoring of firm's behaviour (PRIVMON) and with more elaborated structure of financial sector (FINSTR).

Our findings show that banking sectors with a higher share of interest income relative to the total income (IINC/TINC) as well as banking sectors with higher share of non-interest income relative to total assets (NON/A) are significantly more profitable (see Table 5 and 6), but the significance of this result does not hold in the full sample in the case of ROA.

The coefficient on the cost-to-income ratio is negative and highly significant for all sub-samples in both ROA and ROE. This result is consistent with our expectations and stands in line with Pasiouras and Kosmidou (2007), Athanasoglou et al. (2008) and Dietrich and Wanzenried (2011).

Funding costs (FUNCOST) have a significantly positive impact on bank ROA in countries with strong capital regulation. Such result implies that the role of funding may be not that important as a factor influencing bank profitability proxied by ROA. The impact of funding costs on bank ROE is mixed, as it exerts a significantly negative impact on ROE in countries with strong private monitoring (PRIVMON), but in countries with restrictive official supervisory authorities (OFFSUP), with restrictive capital regulations (CR) and with more sophisticated financial structure this influence is positive and statistically significant.

As to banking sector size the impact is positive and statistically insignificant in most subsamples. Only those banking sectors in countries with better private monitoring of banks (PRIVMON) is this relationship positive. Overall, our result is in line with Athanasoglou et al. (2008).

The empirical results show that concentration affects bank profitability negatively and this effect is statistically significant (see table 5 and 6). Hence, our study is consistent with previous studies that found no support for the structure-conduct-performance (SCP) hypothesis (see e.g. Staikouras and Wood, 2003; Pasiouras and Kosmidou, 2007; Athanasoglou et al., 2008).

The impact of indicators of macroeconomic conditions on ROA is significant in almost all sub-samples except for the full sample. The positive impact of GDPG on ROA is consistent with Pasiouras and Kosmidou (2007), Athanasoglou et al. (2008), Albertazzi and Gambacorta (2009) and Mirzaei et al. (2013). The positive and statistically significant influence of 
short-term interest rate (MMIR) holds only for countries with better investor protection and more developed financial sector. Long-term interest rate (LTIR) is negatively related with ROA and this relationship is statistically significant in almost all sub-samples but not for the full sample.

In contrast to ROA, the results for the impact of macroeconomic conditions on ROE are mixed. The real growth of GDP has a significantly negative impact on ROE in all sub-samples except for PRIVMON and CR countries. The positive effect of short-term interest rate on ROE is statistically significant in the full sample and in the FINDEV sub-sample and contradicts the findings of Albertazzi and Gambacorta (2009), who found negative impact of MMIR on ROE. Referring to the long-term interest rate, it exerts negative effect on ROE. However, this influence is statistically significant in the full sample and in the FINDEV and FINSTR sub-samples. This result implies that rising long term interest rates reduce the profitability of banking sector and is in opposition to findings of Gambacorta and Albertazzi (2009).

Table 7 summarizes the empirical results for our both profitability measures. Again, the results in column 1 refer to the full sample of countries considered simultaneously. Columns 2 to 6 refer to country sub-samples singled out according to the political regions criteria.

Referring to the European sub-sample, we find that the impact of credit risk (proxied by LLP/LOANS) on ROA and ROE is statistically significant and negative. The role of the other risk measures is statistically insignificant except for solvency risk proxied by CAP, which has a negative influence on ROE. Interestingly, the impact of LLP/LOANS on ROA is weaker in the EU sub-sample, and stronger in the EURO area sub-sample. As for the ROE, the effect of LLP/ LOANS is stronger in the EU sub-sample.

Both net interest income and non-interest income affect European banks' profitability (ROA and ROE) in the anticipated way. The influence of those two variables on ROA and ROE is slightly stronger in the EU sub-sample.

We find that the impact of cost-to-income (C/I) on ROA and ROE is statistically significant and negative. This effect is marginally stronger in the EU sub-sample. Funding costs do seem to reduce ROA in the EU, but do not affect EU's ROE significantly.

As to banking sector size, the impact is positive and statistically insignificant in most subsamples. In European countries we find significantly negative impact of SIZE on banking sectors profitability.

Our findings for the influence of concentration ratio on ROA contradict the SCP hypothesis in European banking sectors as well as in EU and EURO area sub-samples. Concentration does not affect ROE significantly in the above mentioned sub-samples as well.

Macroeconomic environment influences both ROA and ROE in the European sub-samples. We find that GDPG exerts positive impact on ROA. This impact is stronger in the EU and the strongest in the EURO area sub-samples. Such a finding implies that, in particular EURO area banking sectors ROA is more sensitive to changes in GDPG. As for the ROE, we find negative relationship between GDPG and ROA, and this relationship is a little bit stronger in the EU subsample.

Whereas short-term interest rates have a positive and statistically significant impact on both our profitability measures in Europe, the EU and EURO area, the influence of long term interest rate is negative. As for the Europe and EU sub-sample the sensitivity of ROE to changes in MMIR and LTIR is twice the sensitivity of ROA. 


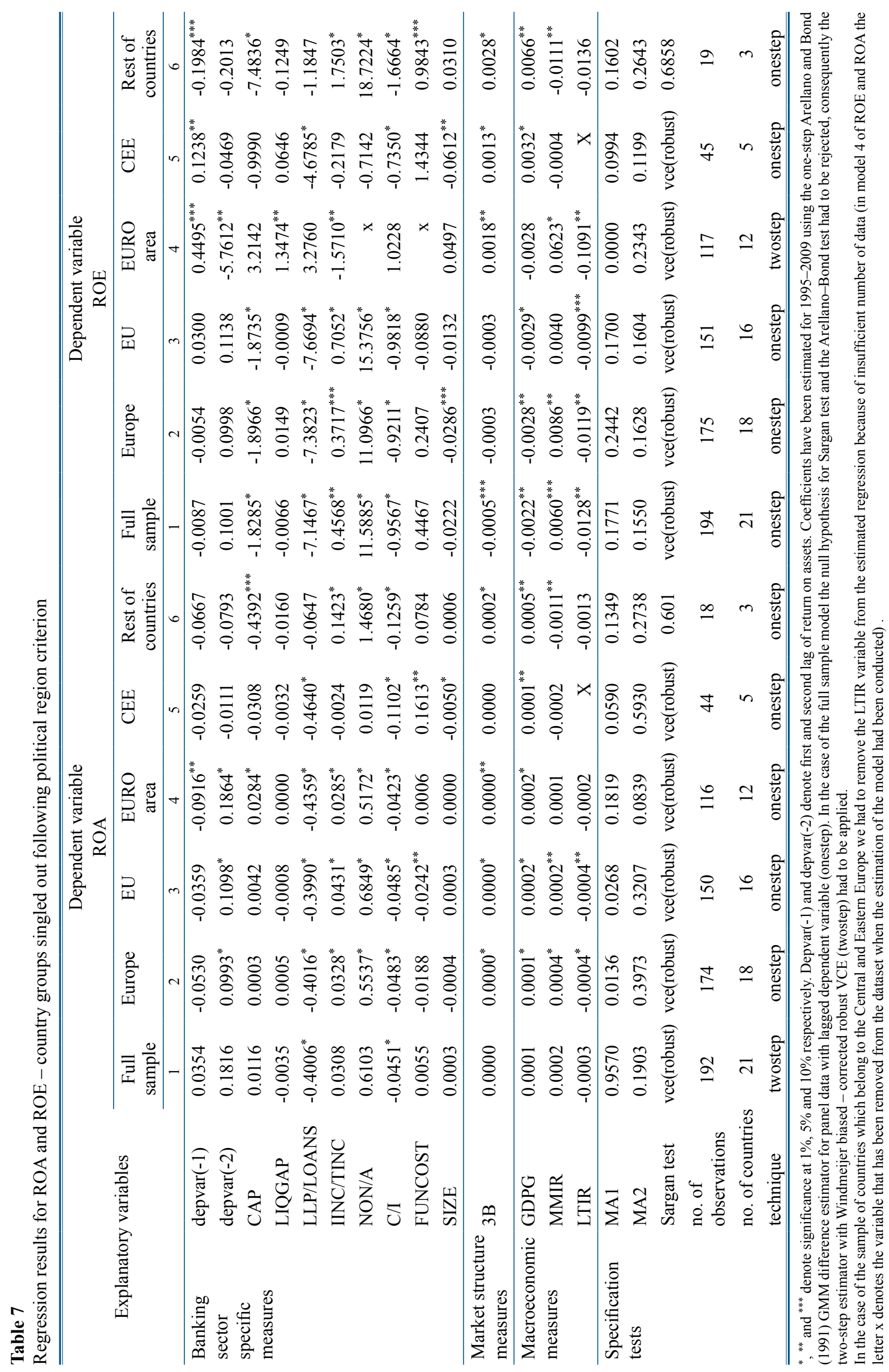




\section{CONCLUSIONS}

This paper has examined how bank specific characteristics, market structure and macroeconomic factors affected the profitability of banking sectors in 21 OECD countries over the period from 1995 to 2009.

Our results confirm findings from previous studies on bank profitability. Overall, we observe some significant differences between the estimation results of the different country samples, both with respect to the significance and the size of the coefficients.

The risk proxies influence both ROA and ROE, but their impact is mixed. On the one hand, bank ROA declines with rising solvency risk. But on the other hand, the higher the solvency risk the higher the ROE. Referring to liquidity risk, the results are mixed too. The liquidity gap in the full sample is statistically insignificant and negative for both ROA and ROE, but in country sub-samples it turns out to be significant determinant. Credit risk exerts negative and statistically significant influence on banking sectors profitability. Its impact is stronger, (i.e. more negative) in countries with better investor protection and with more elaborated structure of financial sector. Interestingly, the impact of credit risk on ROA is weaker in the EU sub-sample, and stronger in the EURO area sub-sample. As for the ROE, the effect of credit risk is stronger in the EU sub-sample.

As for income-sources and cost-efficiency factors, our findings show that banking sectors with a higher share of interest income relative to the total income as well as banking sectors with a higher share of non-interest income relative to total assets are significantly more profitable. The influence of these two variables on ROA and ROE is slightly stronger in the EU sub-sample. The coefficient on the cost-to-income ratio is negative and highly significant for all sub-samples in both ROA and ROE. Funding costs have a significantly positive impact on bank ROA in countries with strong capital regulation. Such a result implies that the role of funding may be not that important as a factor influencing bank profitability proxied by ROA. The impact of funding costs on bank ROE is mixed, as it exerts significantly negative impact on ROE in countries with strong private monitoring of banks. But in countries with restrictive official supervisory authorities, with restrictive capital regulations and with a more sophisticated financial structure this influence is significantly positive. The effect of $\mathrm{C} / \mathrm{I}$ on ROA and ROE is also marginally stronger in the EU sub-sample.

The empirical results for concentration show, consistently with previous studies, that bank profitability is affected negatively by market structure and the results do not support the structureconduct-performance (SCP) hypothesis.

The impact of indicators of macroeconomic conditions on ROA is significant in almost all sub-samples but not for the full sample. We find that GDPG exerts positive impact on ROA. This impact is stronger in the EU and the strongest in the EURO area sub-samples. The results for the influence of macroeconomic conditions on ROE are mixed. Real GDP growth has a significantly negative impact on ROE in all sub-samples except for countries with strong investor protection and with more restrictive capital regulations.

The positive and statistically significant influence of short-term interest rate holds only for countries with better investor protection and a more developed financial sector. The long-term interest rate is negatively related with ROA as well as ROE, and this relationship is statistically significant in almost all sub-samples, but not for the full sample. 


\section{References}

Abreu M., Mendes V. (2002) Commercial Bank Interest Margins and Profitability: Evidence from E.U. Countries. Working Paper Series, Porto.

Albertazzi U., Gambacorta L. (2009), Bank profitability and the business cycle. Journal of Financial Stability 5 (2009), pp. 393-409.

Arellano M., Bond S.R. (1991), Some Tests of Specification for Panel Data: Monte Carlo Evidence and an Application to Employment Equations, Review of Economic Studies, Vol. 58, No. 2, April.

Athanasoglou P.P., Brissimis S.N., Delis M.D. (2008) Bank-specific, industry-specific and macroeconomic determinants of bank profitability. Journal of International Financial Markets, Institutions \& Money 18 (2008), pp. 121-136.

Barth J.R., Caprio G. Jr., Levine R. (2006) Rethinking Bank Regulation. Till Angels Govern. New York: Cambridge University Press.

Barth J.R., Caprio G. Jr., Levine R. (2013) Bank Regulation and Supervision in 189 Countries from 1999 to 2011. Available at: http://faculty.haas.berkeley.edu/ross_levine/Papers/Bank_Regulation_and_Supervision_ Around_the_World_15JAN2013.pdf

Barth J.R., Lin Ch., Ma Y., Seade J., Song F.M. (2013) Do bank regulation, supervision and monitoring enhance or impede bank efficiency? Journal of Banking \& Finance 37, pp. 2879-2892, DOI: 10.1108/ S1569-3767(2013)0000014009.

Beck T., Demirgüç-Kunt B., Levine R. (2009) Financial Institutions and Markets across Countries and over Time. Data and Analysis. Policy Research Working Paper 4943, World Bank.

Beck T., Levine R. (2002) Industry growth and capital allocation: does having a market- or bank-based system matter? Journal of Financial Economics 64, pp. 147-180.

Berger A.N., Humphrey D.B. (1997) Efficiency of Financial Institutions: International Survey and Directions for Future Research, Federal Reserve System, Board Of Governors, Finance And Economics Discussion Series, No. 11.

Berger A.N., Mester L.J. (1997) Inside the Black Box: What Explains differences in the Efficiencies of Financial institutions?, Journal of Banking and Finance, Vol. 21, No. 7, pp. 895-947.

Berger A., (1995) The profit-structure relationship in banking: tests of market - power and efficient - structure hypotheses. Journal of Banking and Finance, Vol. 21, No. 7, pp. 895-947.

Berger A., Bonime S.D., Covitz D.M., Hancock D., (2000) Why are bank profits so persistent? The roles of product market competition, informational opacity, and regional/macroeconomic shocks. Journal of Banking and Finance 24 (7), pp. 1203-1235, DOI: http://dx.doi.org/10.1016/S0378-4266(99)00124-7

Bikker J.A., Hu H. (2002) Cyclical Patterns in Profits, Provisioning and Lending of Banks, DNB Staff Reports, No. 86, Amsterdam.

Borio C., Furfine C., Lowe P. (2001) Procyclicality of the financial system and financial stability: issues and policy options. BIS Papers No 1, Basel: Bank for International Settlements.

Bourke P. (1989) Concentration and other determinants of bank profitability in Europe, North America and Australia. Journal of Banking and Finance 13 (1), pp. 65-79.

Brissimis S.N., Delis M.D., Papanikolaou N.I. (2008) Exploring the nexus between banking sector reform and performance: evidence from newly acceded EU countries. Journal of Banking and Finance 32 (12), pp. 2674-2683, DOI: http://dx.doi.org/10.1016/j.jbankfin.2008.07.002

Chen X. (2007) Banking deregulation and credit risk: Evidence from the EU. Journal of Financial Stability 2 , pp. 356-390, DOI: 10.1016/j.jfs.2006.11.002

Claessens S., Kose M.A., Terrones M.E. (2010) The global financial crisis: How similar? How different? How costly? Journal of Asian Economics 21, pp. 247-264, DOI: 10.1016/j.asieco.2010.02.002

Demirgüç-Kunt A., Detragiache E. (2002) Does deposit insurance increase banking system stability? An empirical investigation. Journal of Monetary Economics 49, pp. 1373-1406, DOI: http://dx.doi.org/10.1016/ S0304-3932(02)00171-X

Demirguc-Kunt A., Huizinga H. (2000) Financial structure and bank profitability. Policy Research Working Paper Series 2430. The World Bank, DOI: http://dx.doi.org/10.1596/1813-9450-2430.

Demirgüç-Kunt A., Huizinga H. (1999) „Determinants of Commercial Bank Interest Margins and Profitability: Some International Evidence", The World Bank Economic Review, Vol. 13, pp. 430-455.

DeYoung R., Rice T. (2004) Noninterest income and financial performance at US Commercial Banks", Financial Review, Vol. 39, pp. 101-127, DOI: 10.1111/j.0732-8516.2004.00069.x

Dietrich A., Wanzenried G. (2011) Determinants of bank profitability before and during the crisis: Evidence from Switzerland. Journal of International Financial Markets, Institutions \& Money 21(2011), pp. 307-327, DOI: $10.1016 /$ j.intfin.2010.11.002

Djankov S., La Porta R., Lopez-de-Silanes F., Shleifer A. (2008) The law and economics of self-dealing. Journal of Financial Economics No 88, pp. 430-465, DOI: http://dx.doi.org/10.1016/j.jfineco.2007.02.007 
Djankov S., McLiesh C., Shleifer A. (2007) Private credit in 129 countries. Journal of Financial Economics No 84, pp. 299-329.

Fiordelisi F., Marques-Ibanez D., Molyneux P. (2011) Efficiency and risk in European banking. Journal of Banking \& Finance 35, pp. 1315-1326.

Fonseca A.R., González F. (2008) Cross-country determinants of bank income smoothing by managing loan-loss provisions, Journal of Banking \& Finance 32, pp. 217-228.

Foos D., Norden L., Weber M., 2010, Loan growth and riskiness of banks, Journal of Banking \& Finance 34, pp. 2929-2940, DOI: http://dx.doi.org/10.1016/j.jbankfin.2010.06.007

García-Herrero A., Gavilá S., Santabárbara D. (2009) What explains the low profitability of Chinese banks? Journal of Banking and Finance 33, pp. 2080-2092, DOI: 10.1016/j.jbankfin.2009.05.005

Goddard J., Molyneux P., Wilson J. (2004) The profitability of European Banks: a cross-sectional and dynamic panel analysis. Manchester School 72 (3), pp. 363-381, DOI: 10.1111/j.1467-9957.2004.00397.x

Goddard J., Liu H., Molyneux P., Wilson J.O.S. (2011) The persistence of bank profit. Journal of Banking \& Finance 35, pp. 2881-2890, DOI: http://dx.doi.org/10.1016/j.jbankfin.2011.03.015

Golin J. (2001) The Bank Credit Analysis Handbook: A Guide for Analysts, Bankers and Investors. John Wiley \& Sons, Asia.

Hume M., Sentance A. (2009) The Global Credit Boom: Challenges for Macroeconomics and Policy, Journal of International Money and Finance 28 (2009), pp. 1426-1461, DOI: 10.1016/j.jimonfin.2009.08.009

Jiménez G., Saurina J. (2006) Credit cycles, credit risk, and prudential regulation. International Journal of Central Banking (2), pp. 65-98.

Laeven L., Majnoni G. (2003) Loan loss provisioning and economic slowdowns: too much, too late?, Journal of Financial Intermediation 12(2003), pp. 178-197.

Leuz Ch., Nanda D., Wysocki P. (2003) Earnings management and investor protection, Journal of Financial Economics 69, pp. 505-527.

Liu Ch.-Ch., Ryan G.S. (2006) Income Smoothing over the Business Cycle: Changes in Banks' Coordinated Management of Provisions for Loan Losses and Loan Charge-Offs from the Pre-1990 bust to the 1990s Boom. The Accounting Review, Vol. 81, No. 2, pp. 421-441.

Lozano-Vivas A., Pasiouras F. (2010) The impact of non-traditional activities on the estimation of bank efficiency: international evidence. Journal of Banking \& Finance 34, pp. 1436-1440.

Micco A., Panizza U., Yanez M. (2007) Bank ownership and performance. Does politics matter? Journal of Banking and Finance 31 (1), pp. 219-241, DOI: http://dx.doi.org/10.1016/j.jbankfin.2006.02.007

Mirzaei A., Moore T., Liu G. (2013) Does market structure matter on banks' profitability and stability? Emerging vs. advanced economies. Journal of Banking \& Finance 37, pp. 2920-2937, DOI: http://dx.doi.org/10.1016/j. jbankfin.2013.04.031

Molyneux P., Thornton J. (1992) Determinants of European Bank Profitability: A Note. Journal of Banking and Finance 16 (6), pp. 1173-1178.

Pasiouras F., Kosmidou K. (2007) Factors influencing the profitability of domestic and foreign commercial banks in the European Union. Research in International Business and Finance 21 (2), pp. 222-237, DOI: 10.1016/j. ribaf.2006.03.007

Short B. (1979) The relation between commercial bank profit rates and banking concentration in Canada, Western Europe and Japan. Journal of Banking and Finance 3 (3), pp. 209-219.

Smirlock M. (1985) Evidence of the non-relationship between concentration and profitability in banking. Journal of Money, Credit and Banking 17(1), pp. 69-83.

Staikouras C., Wood G. (2003) The determinants of bank profitability in Europe. In: European Applied Business Research Conference Proceedings, Venice. 